\title{
Muslim Private Higher Educational Institutions in Malaysia: Issues and Challenges
}

\begin{abstract}
Rosnani Hashim*
Abstract: Privatisation of higher education is a global trend. There is an increasing demand for higher education due to the nature of work and economy today, and public universities and colleges cannot meet the demand with their limited financial resources from the government. Private higher education institutions (PHEI) seem to be the most attractive alternative to public universities and colleges in opening greater access to higher education. Malaysia is no exception, having about 25 private universities, 22 private university colleges and 410 private colleges and institutes. About a fourth of these PHEls are Islamic institutions going by the name of the institutions or their ownership. However, private higher education institutions have their own issues and challenges. The most serious of them are preserving the philosophical goal of a balanced and integrated education despite market demands and sustaining its operation financially amidst a competitive environment. Yet, there are several opportunities for Islamic PHEls especially in terms of international collaboration and exchanges. This article is an attempt to examine these issues and challenges or opportunities.
\end{abstract}

\section{Introduction}

Beginning in the 1990s, there has been a greater demand for private higher education worldwide. It is the fastest growing segment of post-secondary education in the twenty-first century. This is due to the increasing demand for university education and the lack of places in public universities. There are several factors responsible for the increasing demand. There is increasing competition at lower levels of education and increasing pressure for students to succeed and for parents to invest in their child to succeed academically. Secondly, there is a realisation that university education brings in a higher rate of return and this spurs more students to attend university. Thus, from a university meant only for elites, it has been transformed to one that is meant for the masses. This greater demand for university education has pressured universities to accept more students, sometimes exceeding their capacity and resources. Since the universities are public institutions supported by public finances, increase in demand

* Rosnani Hashim is Professor of Education at the Institute of Education, International Islamic University Malaysia (IIUM), Kuala Lumpur, and also Associate Director of the Centre for Philosophical Inquiry in Education (also at IIUM). 
also meant an increased pressure on public finances because universities are more expensive per student than lower levels of education. Since government cannot meet the demand, private universities have become the alternative.

Besides the increasing demand for higher education as a natural process of the improvement and successes of the lower education which resulted in the growth of private education, another impetus for private higher education is the aspiration for quality education as well as for different types of education in response to the needs of the contemporary, modern society. Advocates of privatisation ${ }^{1}$ argue that the private sector is more efficient, effective and responsive to the rapid changes needed in the modern world while the public sector has been described as wasteful, slow, unresponsive and bureaucratic.

\section{What Private Higher Education Means}

With the emergence of private education, universities became more customer-oriented and resource-driven to meet the challenges of a changing environment. More tools and concepts from industry were brought into higher education management to ensure its efficiency. The survival of the universities is no longer guaranteed by a beneficent government. It has to draw up its own strategic long term plan including marketing its programme to its 'customers' and pleasing its 'stake holders'. Controlling resources and finding new markets has become unavoidable for universities. The university management needs to adopt practices and training methods used by commercial management. As a consequence universities have been drawn closer to the market in many ways:

1. creating more links with the industry,

2. establishing commercial arms (or Strategic Business Units),

3. raising tuition fees,

4. selling education to foreign students and

5. restructuring campuses.

What is increasingly evident is that globalisation has brought market and business practices into universities, linked universities to markets and reshaped universities with a business mentality. Programmes being offered are determined by the needs of industries and not by the goals of education in producing the good, wholesome and integrated man. Man's physical need is given greater attention than his intellectual, humanistic and spiritual needs. In a sense globalisation has resulted in the dehumanisation of man. It has reduced knowledge to a commodity which like any goods can be exchanged for a profitable sum of money and whose value is determined by market demand. Consequently, the traditional courses that are essential for higher goals of intellectual and humanistic development such as philosophy, sociology, 
literature, music and history are beginning to take a backseat or are completely ignored, and courses needed for the industry especially management, finance and marketing are given top priority. Thus, universities have abdicated their role as an active independent public critic because those courses that encourage critical thinking, critical inquiry and reflection on society have been marginalised. On the other hand, universities are aligning themselves with specific market forces especially through research grants and internships which in a way have tied them down from speaking against these forces even if they should.

\section{Shifts due to Privatisation of Higher Education}

Privatisation of higher education has brought about several changes. First, there is a shift in aims from aspiration for knowledge as a good to that of the market as the good. Subsequently universities become more focused on generating and disseminating knowledge in order to generate profit rather than on enlightening society, and therefore are to be run according to 'busnocratic rationality', where the choice of the student (the customer) is everything. ${ }^{2}$ Which courses to teach, which research initiative to fund, which funding agencies to approach, which student market to serve, which enrolment policy to adopt - are now considered in terms of detailed cost revenue calculations rather than by academic criteria. Second, there is a shift in the role of the lecturer - from that of a scholar to that of an entrepreneur who brings research grants and contracts. The cult of efficiency has led to increasing financial pressures to 'do more with less'.

Third, there is the shift in relationship among the lecturers within the same institution, from one of collegiality where there is mutual respect and support, to managerialism which entails accountability via quantity and quality assurance exercises, a lot more standards such as ISO 2000 for teaching and learning, and local and international university rankings. In some cases, there is also a shift in power from the faculty to the central administration. Fourth, a major shift occurs in the role of the academician from 'the sage on the stage' to 'the guide on the side'. Traditional forms of pedagogy in higher education also face challenges from the 'virtual pedagogy'. Fifth, there is a shift towards internationalisation with the establishment of branches of foreign universities in a host country or twinning programmes between the local tertiary institution and another foreign university. The popularity of these programmes arose from the assumption that having these branch universities or twinning programmes would help increase the quality of the educational programme of the host country. But it should be borne in mind that these arrangements can adversely affect the local culture, transforming it to become culturally dependent on the foreign investor or even led to cultural relativism. This is particularly evident in the dominance of English language in the host country. Finally, privatisation of 
higher education can transform a university focus from research to teaching due to its market driven policies.

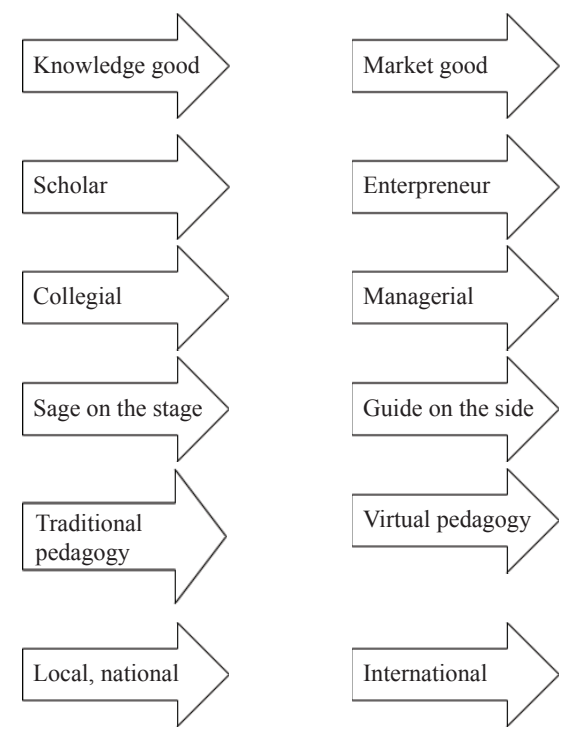

Figure 1: $\quad$ Shifts due to privatised higher education

Ideally speaking, the private sector should complement and supplement the efforts of the public sector, but this is not the case. Surveys show that private universities have tended to leave some of the more difficult and costly tasks to the public sector. Most private universities are located in the capital and its vicinity. Therefore they are not helping in the development of the rural regions. In addition, many of these institutions offer courses in areas such as accountancy, law, business administration and computer sciences which do not require large capital outlay.

\section{Muslim Higher Education in the Classical Period}

Private education was always the norm in the Muslim classical period. Teaching and learning occurred in the homes of the learned, salons, shops, libraries, palaces, hospitals and observatories. ${ }^{3}$ According to George Makdisi,

Pre-madrasah institutions exclusive of the foreign sciences were the jami' with their halqa and the masjid; those inclusive of these sciences were the various institutions whose designations included the terms dar, bait, khizana, essentially libraries, as well as the hospitals, maristans, from the Persian bimaristan. 
Islamic science reached its glorious stage during this period. It was only later, in the late eleventh century, that the Seljuk vizier Niẓām al-Mulk introduced the madrasah, a form of higher education institution, and endowed it with awqa $f$ (endowments) for teachers and students. It was an institution of learning par excellence but the curriculum was devoted to the study of law. The mosque, from which the madrasah developed, continued to be an institution used for the teaching of the various Islamic sciences, including that of the law. The mosque could be devoted to any particular sciences according to the wishes of the founder, whereas the madrasah focused primarily on law, although ancillary sciences were also taught. ${ }^{5}$ With the advent of the madrasah, the institutions that included foreign sciences began to fade away, becoming extinct by the twelfth century. Thereafter, this limited curriculum became the model for Islamic education throughout the Muslim world - whether private or community based, for example, Cairo's Al-Azhar (970 CE) and the one in Kairouan in what is now Tunisia (859 CE).

\section{Muslim Private Education Institutions in Malaysia}

Private education institutions flourished in Malaya before the advent of the British. The famous Malayan writer Munshi Abdullah (d. 1854) reports the existence of qur'ānic classes for learning the Qur'ān and Malay language classes in the homes of teachers in the late eighteenth century. ${ }^{6}$ In the Malay world, village-based pondoks later came into existence and were located around the home of the tuan guru (or teacher). After the First World War, madrasahs or the more regulated schools began to be established by the community. These learning institutions were private (either owned and established by the teacher or by the community). They were not profitoriented but rather service-oriented. They were set up to fulfil the social obligation of educating the community. At the end of the 1970s and early 1980s, Muslim groups and non-government organisations began to set up their own kindergartens (Taski), Islamic primary schools (SRI), and Islamic secondary schools (SEMI). These kindergarten and schools were owned by organisations such as ABIM (Angkatan Belia Islam Malaysia) and JIM (Jemaah Islamiah Malaysia) which were not profitoriented but fulfilling a social obligation. It was only later in the 1990s that profitoriented Muslim private schools such as Adni, Setiabudi, International Islamic School and Seri Chempaka began to operate.

\section{Muslim Private Higher Education Institutions (PHEI) in Malaysia}

The development of PHEIs in Malaysia has been encouraged through the Education Act of 1996, which allows for the establishment of private higher education institutions, branch campuses of foreign universities, and corporatisation of public universities and also instituted a National Accreditation Board for quality assurance. 
The privatisation of higher education arose due to the lack of places in public higher institutions of learning, the ethnic quota system, the need to save on foreign exchange, because of the 1997 financial crisis that resulted in the devaluation of the Malaysian ringgit, and the high cost of studies abroad. The number of private educational institutions has increased from 156 in 1992 to 707 in 2002.7 In 1995, there was no private university, but by 2002 , there were twelve private universities. The number of students enrolled in these private institutions rose from about 35,600 in 1990 to about 203,000 in 2000 which accounted for 53 percent of the total number of tertiary students.

Privatisation of higher education in Malaysia may take the form of transferring the ownership of public institutions, allowing the establishment of private institutions, or corporatising public universities. Over the years, different modes of ownership have been developed for private higher education, some of which are profit-oriented enterprises while others are non-profit. Profit-making institutions are set up by individual proprietors, private companies, consortia of companies, public listed companies and government corporations. On the other hand, non-profit educational institutions are set up by foundations or philanthropic organisations, and through community financing. The PHEIs also differ in their market focus, some offering a wide range of programmes in various fields of studies from pre-university to post-graduate level, while others specialize in specific areas such as medical fields, art and design, language, business studies, music and information technology. The latter group desire to carve a niche market for themselves instead of competing on the same ground with the other colleges. In this way they become more responsive to changing labour market needs. The programmes offered by PHEIs in Malaysia can be broadly categorised into three groups, namely, (i) internal programmes, (ii) transnational programmes, and (iii) programmes leading to qualifications awarded by external bodies.

For the purpose of discussion, a Muslim PHEI is defined as a higher education institution with one of the following characteristics: about 30 percent of its equity is owned by Muslims, 50 percent of its management and academic staff are Muslims, or at least 50 percent of its students are Muslims. In 2002, there were 120 Muslim PHEIs with 60,000 students out of a total 666 PHEIs with 232,069 students. The student population of the Muslim PHEIs forms about 25.8 percent of the total number of students in PHEIs, of which 20,000 or almost a third are sponsored. In 2005, 123 Muslim PHEIs had to close down, with 30 more in critical condition due to lack of students with financial aid. ${ }^{8}$

The latest figures obtained from the Ministry of Higher Education indicate that there are currently (in 2011) 455 PHEIs in operation (Fig. 1). Of these, 25 (5.49\%) are private universities, $22(4.83 \%)$ are university colleges, and $408(89.68 \%)$ are private colleges, institutes and academies. These figures are in contrast to 20 public universities and 27 polytechnics. There are also five branch campuses of foreign 
universities such as the University of Nottingham and Monash University. Eight (32\%) of the 25 private universities and eight (36\%) of the 22 university colleges are Muslim PHEIs.

Most private higher education institutions are owned by foundations, corporations, government local companies (GLCs), religious institutions, family business, political organisations and foreigners.

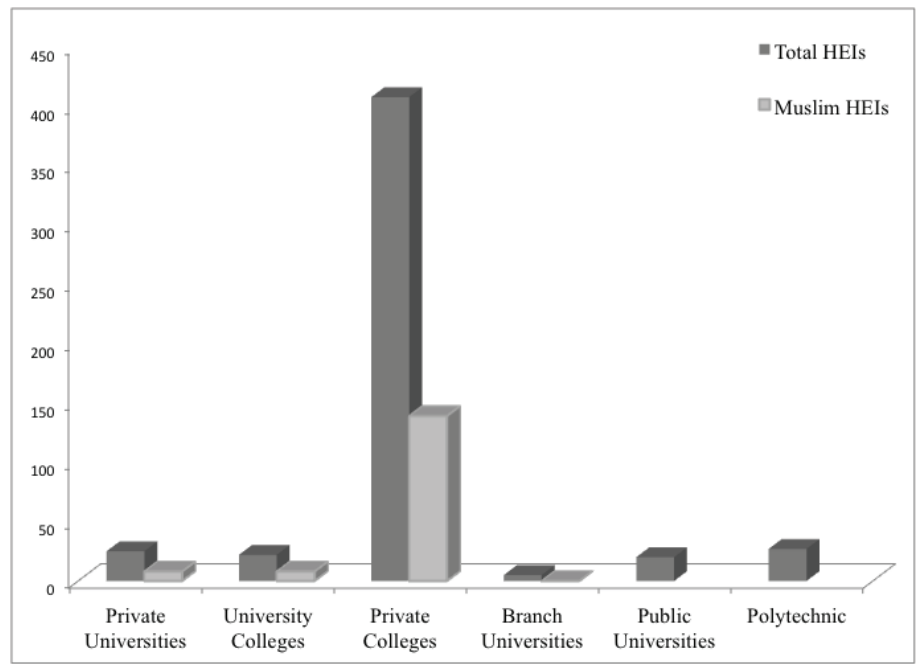

Figure 2: Comparison of Muslim PHEIs and others

\section{Issues and Challenges}

The most significant issue faced by many Muslim operators of private higher education is financial. The availability of funds determines the survival of the PHEIs in this competitive market. The other issues are related to their management, programme/ curriculum, academic staff and marketing and business development division. These issues were drawn to the attention of the writer based on her experience in dealing with a private Islamic International College, a private Islamic International School and Muslim PHEIs in general.

\section{Finance and Quality Education}

It cannot be denied that quality education is positively related to a healthy and sound financial position. With a healthy financial position, the institution can select outstanding teachers, improve its teaching and learning resources, provide up-to-date facilities and support conducive learning environments including accommodation. 
There are several issues related to finance. About 80 percent of the Muslim PHEIs depend on student fees. These students are from poor families, who are largely dependent on the PTPTN, a national body which give loans to students in higher education. In 2005, 75 percent of the families earned less than MYR 1,500 per month. When the amount of loans available from PTPTN in 2005 was reduced, many students had to quit, leaving the institutions in a dilemma. The other issues related to finance are as follows:

- poor collection of fees due to laxity or a poor system of collection that allows the accumulation of bad debts that become uncollectible;

- poor record-keeping and auditing;

- poor knowledge of finance and investment;

- wastage.

\section{Management Issues}

The management of private education institutions plays an important role in ensuring that the system is efficient, professional, transparent, ethical, of high integrity, able to deliver on time, customer- and market-oriented and dynamic. The major issue is not having good leadership. Many Muslim PHIEs seem to suffer from the following problems:

- Leadership that lacks vision, ideas, creativity, analytical skills, social skills, and the ability to be a 'pathfinder';

- un-Islamic or unprofessional work ethics such as lack of punctuality and frequent absences;

- lack of integrity in dealing with money;

- adopting the civil service and not the private company attitude relaxed, cannot work beyond office hours, not competitive and lacking commitment;

- not rewarding or appreciating key people, and loyal and good staff;

- lack of management with motivation skills and of staff professional development.

\section{Business Development and Marketing}

Business development and marketing are very important aspects of private education enterprise. Without the ability to market its programme and explore available opportunities, the institution will not be able to withstand the competition of in vying for the best students and resources. The problems with Muslim PHEIs are, among others: 
- lack of marketing knowledge and strategies;

- targeting only one segment of the market: for example, only Muslims;

- lacking a practical and comprehensive business plan

- insufficient funds for aggressive marketing and expansion

\section{Academic Programmes}

The curriculum or academic programmes offered by an institution as well as its philosophy are crucial in its ability to draw the best students, aside from the attraction of competitive tuition fees and excellent academic achievement. This should be one of the major elements in distinguishing a Muslim PHEI from the non-Muslim. Also the curriculum and programme offerings are important because of the ability of graduates of the programme to obtain employment and to contribute back to the community. Some issues related to this aspect are as follows:

- narrow curriculum scope, sometimes focused only on Islamic or social and human science packages (the least cost);

- no core courses to unify knowledge and the world view.

- courses not offered from the Islamic worldview;

- not sensitive to the market demands and needs.

\section{Academic Staff}

Another factor that enhances an institution is the reputation of the academic staff. The more prominent nationally and internationally a professor, the more prestigious the institution where he teaches. However, the institution has to be prepared financially to attract these academic 'stars'. Usually, their salaries are higher commensurate with their qualifications and experience. However, in practice most PHEIs tend to fall short on this factor in trying to cut costs. The issues related to academic staff are as follows:

- high turnover rate;

- poorly prepared or inadequate staff, due to financial constraints;

- $\quad$ staff lacking Islamic knowledge, character and/or work ethics;

- high numbers of part timers, who lack ownership and a sense of belonging, who may not be committed or willing to make sacrifices;

- staff who lack of vision, ideas, and creativity, with a 'work for a living' attitude only; not self-initiating.

\section{Reflection}

Based on the issues and challenges faced by Muslim PHEIs as described in the previous section, Muslim policy makers and educators have to pause and reflect. 
They need to consider some pertinent questions in their search for a proper direction. What is the crux of the matter? Do Muslims need Muslim or Islamic PHEIs? If so, what should be their philosophy? In the context of Malaysia, do Muslims today face the problem of access to higher education as they did from the 1950s to the 1980s? Does privatisation of education mean an abandonment of Islamic ideals of education? Would Muslim PHEIs allow for greater autonomy and academic freedom, two vital values which are being slowly eroded in public universities? Should Muslim PHEIs be concerned with quantity or quality? Should Muslim PHEIs recognise internationalisation as a moral obligation? Could Muslim PHEIs allow for a more focused research on developing the ummah?

\section{The Role of Islamic PHEls}

The first concern of Islamic PHEIs' should be quality and not quantity, especially in countries where access to higher education is not a problem. In fact the Malaysian government has set up additional universities, polytechnics and community colleges to cater for the increasing number of students. Therefore, if there is a need for Muslims to establish private higher education, it should be driven by quality, modelled after Harvard University or the University of Chicago, especially with respect to quality education and a financial base. Since private education is expensive, it should target only on a specific class of the ummah. To avoid only on drawing the wealthy, it should provide scholarships for those who are underprivileged but who have brains and talent. It should not be a mediocre institution only out to make profit by providing more spaces for mediocre students with a mediocre academic staff. But in a society where the Muslims are a minority and access to Islamic knowledge is limited, it is a different matter altogether, and the role of the private institution differs accordingly.

Secondly, there should be concern for ummatic human capital development, which means giving priority to internationalisation and transnational collaboration. A high number of majority Muslim countries are still underdeveloped and lack good human capital. Therefore Muslim PHEIs should extend their services to assist the Muslim ummah throughout the world. This has been a successful function of the International Islamic University Malaysia (IIUM), a public higher education institution. Tables 1 and 2 show the contribution of IIUM in human capital development of Muslims worldwide. This model is now being adopted by the Al-Bukhary International University, a Muslim PHEI. However, Table 3 shows that the contribution of IIUM is mainly in the field of law and Islamic Revealed Knowledge and Human Sciences (IRKHS). It will be more meaningful when more assistance is given to science and technology - science, engineering and medicine - and also to business-related programmes, which are the engines of national economic growth. 


\begin{tabular}{|l|c|c|c|c|}
\hline \multirow{2}{*}{\multicolumn{1}{|c|}{ Country }} & \multicolumn{2}{c|}{2009} & \multicolumn{2}{c|}{2011} \\
\cline { 2 - 5 } & Students & Percent & Students & Percent \\
\hline Malaysia & 14,043 & 84.6 & 15,140 & 86.2 \\
\hline International & 2,551 & 15.4 & 2,421 & 13.8 \\
\hline Total & 16,594 & & 17,561 & \\
\hline
\end{tabular}

Table 1: Human capital: Student enrolment at IIUM

\begin{tabular}{|l|c|c|}
\hline \multirow{2}{*}{ Country } & \multicolumn{2}{|c|}{ Total Students } \\
\cline { 2 - 3 } & $\mathbf{2 0 0 9}$ & $\mathbf{2 0 1 1}$ \\
\hline Indonesia & 308 & 308 \\
\hline Yemen & 188 & 187 \\
\hline Somalia & 186 & 161 \\
\hline Thailand & 179 & 157 \\
\hline Saudi Arabia & 174 & 130 \\
\hline Sudan & 141 & 114 \\
\hline Singapore & 120 & 190 \\
\hline Bangladesh & 116 & 119 \\
\hline India & 79 & 90 \\
\hline Palestine & 82 & 83 \\
\hline
\end{tabular}

Table 2: Top 10 countries of origin of international students at IIUM

\begin{tabular}{|l|c|c|c|c|}
\hline & Malaysia & $\mathbf{( \% )}$ & International & $(\mathbf{\% )}$ \\
\hline Architecture & 1 & 0.5 & 6 & 2.1 \\
\hline Law & 53 & 24 & 54 & 19.1 \\
\hline Economics & 20 & 9 & 17 & 6 \\
\hline Engineering & 7 & 3.2 & 19 & 6.7 \\
\hline Library \& Finance & 4 & 1.8 & 3 & 1.1 \\
\hline Education & 32 & 14.5 & 25 & 8.9 \\
\hline IRKHS & 63 & 28.5 & 127 & 45 \\
\hline ISTAC & 22 & 10 & 27 & 9.6 \\
\hline ICT & 13 & 5.9 & 3 & 1.1 \\
\hline Science & 2 & 0.9 & 1 & 0.4 \\
\hline Medicine & 4 & 1.8 & 0 & 0 \\
\hline
\end{tabular}

Table 3: $\quad \mathrm{PhD}$ graduates by nationality and field of study 
In a survey conducted with 159 alumni of IIUM ${ }^{9}$ it was found that IIUM was not only successful in developing human capital for national development but also in social and religious growth. It was successful in raising the awareness in the alumni of the vision of Islamic education in respect to the unity of knowledge and faith and its integrated nature (Fig. 3); and enhancing their understanding of the Islamic worldview and the transformation of their character (Fig. 4). IIUM was also perceived as successful in sensitising students to the cultural diversity of Muslims and their cultures (Fig. 5).

Unity of Knowledge \& Faith

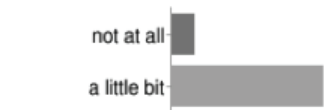

better than before

much more better

very much so

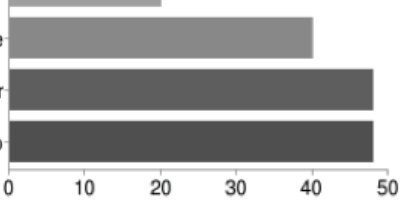

Integration of Knowledge

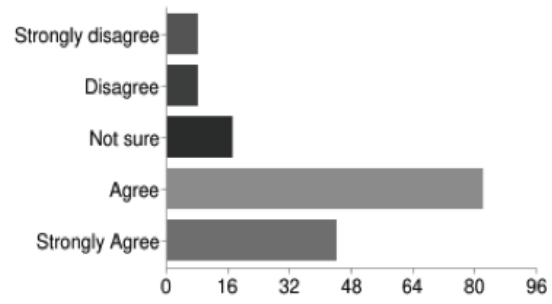

Figure 3: Internationalisation mission of IIUM

Understanding of IWV

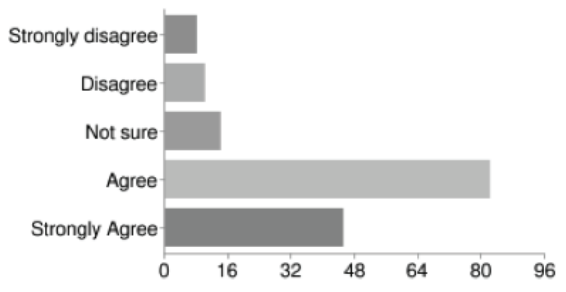

My life has been transformed

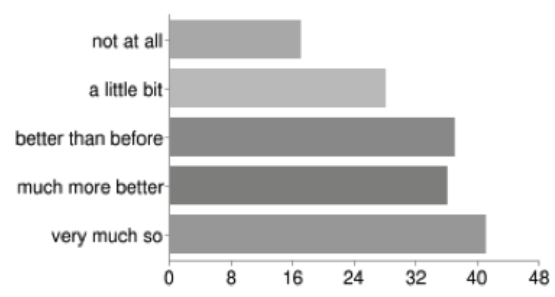

Figure 4: Islamic worldview and character transformation

Awareness of cultural diversity among Muslims

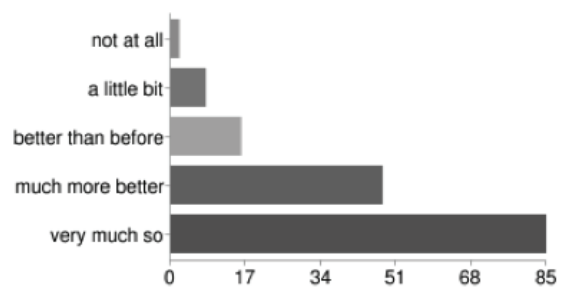

How culturally diverse Muslims think and act

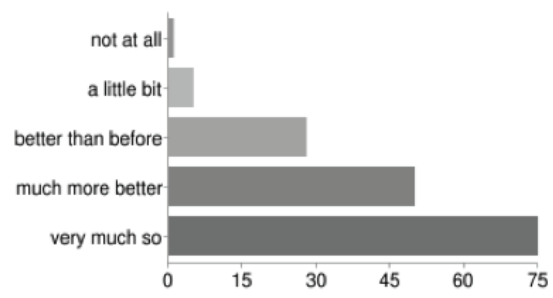

Figure 5: Muslims' cultural diversity 
Thirdly, the Muslim PHEI should attract and engage quality lecturers and professors and ensure that they perform their functions as sages and researchers and not merely as facilitators. Give them their honorific role as experts to guide the policy makers in their fields and the academic freedom to speak their minds. The Muslim PHEIs should seek out experienced university administrators capable of providing a more efficient higher education model.

Fourthly, Muslim PHIEs need to be self-sustaining through the concept of endowment (waqf) and profit making to maintain itself. We cannot separate business from private education. There is no choice. What is most important is that the intent or mission is still Islamic.

Last but not least, Muslim PHEIs should be guided by the tawhidic principles based upon the Qur'ān and the Sunnah of the Prophet Muhammad. This is true especially regarding their codes of conduct and goals.

\section{Conclusion and Recommendations}

Based on the potential contributions of Muslims PHEIs as discussed in the previous sections, it is clear that private higher education has an important role to play. The success of the IIUM in producing societal leaders, 'ulama', professionals and wealthy businessmen demonstrates the importance of Muslim private universities with an international emphasis in order to serve the ummah, which is still in a deep slumber. It is thus an obligation. To move Muslim PHEIs forward, the following recommendations are put forth under three categories: finance, management and programme.

\section{Finance}

This has been the most crucial concern of all Muslim PHEIs and should be addressed accordingly. The suggestions are as follows:

- The finance division should adhere to its collection policy strictly without fear or favour. Muslim parents sometimes practice a double standard when dealing with Muslim institutions. The institution needs to project itself as an Islamic business entity and not as a charitable organisation.

- Muslim authority in the community should mobilize the zakāt fund to invest in PHEIs or provide study loans to Muslim PHEI students.

- Waqf or endowment funds such as the Wakaf Corporation as initiated by the Johor Corporation should be established with the cooperation of State religious councils.

- The institutions should set aside some of their funds for short and long term investments. 
- GLCs are encouraged to diversify into the private education sector.

- Muslims are encouraged to become entrepreneurs to assist in the economic development of the ummah.

\section{Management}

The PHEI management team is crucial for steering the institution in the right direction and also in sustaining itself. It is also responsible for its growth and coping with its challenges. To be successful in these, it is vital for Muslim PHEIs:

- To recruit excellent Chief Executive Officers and/or Chairpersons with vision, ideas and vast, educational experience - both locally and internationally. Most importantly, they must be ethical and Islamic in terms of their actions.

- To employ professional accountant, human resource and finance and marketing managers with experience. These positions should be open to non-Muslims if need arises.

- To run the enterprise professionally with proper systems and policies and to be accountable and transparent.

- To develop good business plans and long term strategies.

- To institute quality assurance to ensure the quality of programmes and services.

- To create a sense of ownership and belonging among their staff.

\section{Programme}

Parents are attracted to private higher education for the quality and as an alternative when their children do not get access to public higher education. How can a PHEI be competitive? Muslim PHEIs should:

- offer quality academic programmes that are tailored to the needs of the local and international communities - especially its Muslim clients.

- offer programmes that are sensitive to the changing needs and demands of the market to ensure viability and that are also consistent with the policies of the ministry of higher education.

- offer quality academic programmes that are transnational such as twinning programmes with foreign universities recognised by the Public Service Department, which could be a saving for parents and the country.

- establish linkages and collaboration with local and international universities especially in their niche areas.

- maintain their Islamic identity by making Islamic philosophy or worldview - metaphysics, epistemology, axiology - and some qur'ānic and hadìth sciences as core courses for all disciplines so as to connect the sciences as a unit and to understand the religion $(d \bar{l} n)$ on a higher intellectual plane.

- compete for research grants offered by various agencies and the Ministry of Higher Education. 
- $\quad$ provide community-oriented extra-curricular activities for the development of character, leadership, practical and social skills.

In conclusion, we do need Muslim private higher education institutions with a special purpose: to supplement public higher education institutions and to be free to attain the goals of Islamic education. Our history has shown that private higher education has more energy and creativity to produce innovative products and be more efficient. The only hurdle has been to find ways to finance them. However, the Islamic legacy has left an important device, zakāt and waqf to assist in the growth of PHEIs. We need to have more Muslim philanthropists too who give priority to education rather than the building of mosques. Being private does not mean that Private HEIs will sacrifice their Islamic vision and mission. In fact, PHEIs provide an opportunity for international collaboration and long term socio-economic assistance within the Muslim world.

\section{Notes}

1. World Bank, Constructing Knowledge Societies: New Challenges for Tertiary Education, (Washington DC: World Bank, 2002).

2. Wayne Dreyer and Alexander Kouzmin, "The Commodification of Tertiary Education within a Knowledge Economy," Journal of Economic and Social Policy 13, no. 1 (2009), available online at http://epubs.scu.edu.au/jesp/vol13/iss1/ (accessed on 2 February 2012).

3. Ahmad Shalaby, History of Muslim Education (Beirut: Darul Kashshaf,1954).

4. George Makdisi, The Rise of Colleges: Institutions of Learning in Islam and the West (Edinburgh: Edinburgh University Press, 1981), 9-10.

5. Ibid., 9 .

6. Rosnani Hashim, Educational Dualism in Malaysia: Implications for Theory and Practice (Kuala Lumpur: The Other Press, 2004).

7. Molly N. N. Lee, "Restructuring Higher Education in Malaysia," available online at http://www. cshe.nagoya-u.ac.jp/seminar/kokusai/lee.pdf (accessed on 1 March 2012)

8. See Marzita Abdullah, "IPTS bumiputera terancam: 30 buah dijangka 'gulung tikar' dan menjejaskan masa depan 8,000 pelajar," Utusan Malaysia (Kuala Lumpur), 22 April 2010; Raja Luvena Sharifuddin, "IPTS bumiputera 'gulung tikar': 123 ditutup, 30 'tenat' ekoran masalah kekurangan pelajar," Utusan Malaysia (Kuala Lumpur), 29 May 2010.

9. Rosnani Hashim, "A Survey on Internationalisation of Islamic Higher Education: A Case Study of IIUM" (2011, unpublished). 